\title{
CONFIDENTIALITY CLAUSES IN INVESTOR-STATE CONTRACTS FOR THE PROTECTION OF TRADE SECRETS AFTER PROMULGATION OF THE INDONESIAN ACT ON PUBLIC INFORMATION DISCLOSURE
}

\author{
Sanusi Bintang* \\ Mujibussalim Mujibussalim** \\ Mahfud Mahfud*** \\ Fikri Fikri ${ }^{* * *}$
}

\begin{abstract}
A confidentiality clause is a clause in investor-state contracts which is in the operative part of the contract to guarantee adequate protection of the trade secrets of the contracting parties. This article argues that there is a need to change the current practice where investor-state contracts in Indonesia utilizes broadly defined confidentiality clauses as a means to protect trade secrets in international business transactions. This is because a broadly defined confidentiality clause is contradictory to the provisions of the Act on Public Information Disclosure (APID). APID is aimed mainly at providing public information disclosure. The public information includes public contracts, such as investor-state contracts. Therefore, a new model of the confidentiality clause is needed for the protection of trade secrets as intended by the Act on Trade Secrets (ATS) and contract law as well as public information disclosure as intended by APID. This article employs doctrinal legal research. The research utilized, primary, secondary, and tertiary legal authorities. The primary legal material intensively used in this article consists of mandatoryprimary legal authorities, in the form of statutes and contracts. The contracts used are the investor-state contracts of Aceh Province,
\end{abstract}

* Law lecturer at Faculty of Law, Universitas Syiah Kuala (USK). Email: sanusi@unsyiah.ac.id.

** Law lecturer at Faculty of Law, Universitas Syiah Kuala (USK). Email: mujibussalim@unsyiah.ac.id.

*** Law lecturer at Faculty of Law, Universitas Syiah Kuala (USK). Email: mahfud.abdullah@unsyiah.ac.id.

${ }^{* * * *}$ Law lecturer at Faculty of Law Universitas Syiah Kuala (USK). Email: fikri@unsyiah.ac.id. 
Indonesia. The finding shows that a new model of the confidentiality clause can be created by accommodating both the interest of the state for providing public information disclosure based on APID and the interest of investors for the protection of trade secrets based on ATS and contract law. Investor-state contracts are a specific type of contract which has specific characteristics that apply to both private law and public law. They are different from purely international commercial contracts which only apply private law. Investor-state contract drafters need to be aware of this difference and provide a more balanced confidentiality clause in the contracts.

Keywords: Public Information Disclosure Act, Trade Secrets Act, confidentiality clause, investor-state contracts, intellectual property rights, international investment, public information disclosure, trade secrets.

\title{
FASAL KERAHSIAAN MELIBATKAN KONTRAK PELABUR-NEGERI BAGI MELINDUNGI RAHSIA PERDAGANGAN SETELAH PENGGUBALAN AKTA PENDEDAHAN MAKLUMAT AWAM DI INDONESIA
}

\begin{abstract}
ABSTRAK
Klausa kerahsiaan adalah klausa dalam kontrak pelabur-negeri yang berada di bahagian operasi kontrak untuk menjamin perlindungan secukupnya rahsia perdagangan pihak-pihak yang berkontrak. Makalah ini berpendapat bahawa ada keperluan untuk mengubah amalan di mana kontrak pelabur-negeri di Indonesia menggunakan klausa kerahsiaan yang ditentukan secara luas sebagai cara untuk melindungi rahsia perdagangan dalam transaksi perniagaan antarabangsa. Ini kerana klausa kerahsiaan yang ditentukan secara meluas bertentangan dengan peruntukan Akta Pendedahan Maklumat Awam (APID). Tujuan utama APID adalah untuk memberi pendedahan maklumat kepada orang ramai. Maklumat awam merangkumi kontrak awam, seperti kontrak pelaburnegeri. Oleh karena itu, model baru klausa kerahsiaan diperlukan untuk melindungi rahsia dagang sebagaimana dimaksud dalam Akta Rahsia Perdagangan (ATS) dan undang-undang kontrak serta pendedahan maklumat awam sebagaimana dimaksud oleh APID. Makalah ini menggunakan penyelidikan doktrinal. Penyelidikan ini menganalisa perundangan primer, sekunder, dan pengajian tinggi. Bahan undangundang utama yang digunakan secara intensif dalam makalah ini terdiri daripada perundangan wajib-primer, dalam bentuk statut dan kontrak.
\end{abstract}


Kontrak yang digunakan adalah kontrak pelabur-negeri di Provinsi Aceh, Indonesia. Penemuan kajian ini menunjukkan bahawa model baru klausa kerahsiaan dapat dibuat dengan menampung kepentingan negara untuk memberikan pendedahan maklumat awam berdasarkan APID dan kepentingan pelabur untuk melindungi rahsia perdagangan berdasarkan ATS dan undang-undang kontrak. Kontrak pelabur-negeri adalah jenis kontrak tertentu yang mempunyai ciri khas yang berlandaskan undangundang swasta dan undang-undang awam. Kotrak ini berbeza dengan kontrak komersial antarabangsa yang hanya berlandaskan undangundang persendirian. Penggubal kontrak pelabur-negeri perlu menyedari perbezaan ini dan memberikan klausa kerahsiaan yang lebih seimbang dalam kontrak mereka.

Kata kunci: Akta Pendedahan Maklumat Awam, Akta Rahsia Perdagangan, Fasal Kerahsiaan, kontrak pelaburnegeri, harta intelek, pelaburan antarabangsa, pendedahan maklumat awam, rahsia perniagaan.

\section{INTRODUCTION}

It is often the case that drafters of a government contract often used broadly defined confidentiality clauses aimed at protecting trade secrets. They are usually unaware of the different character of the investor-state contracts which is government contracts with mixed private and public law elements. This is different from purely international commercial contracts, the use of broadly defined confidentiality clause in an investor-state contract is inconsistent with the provision in Act of the Republic Indonesia Number 14 of 2008 on Public Information Disclosure (hereinafter called APID).

As a result, the drafter of the contracts needs to learn the relationship between trade secrets law, contract law and public information disclosure law. ${ }^{1}$ Even though at different levels, there is a tendency to strike a better balance of the protection of private law,

1 The main source of trade secret law is Act of the Republic of Indonesia Number 30 of 2000 on Trade Secrets (ATS). While the main source of contract law is the Indonesian Civil Code (ICC), and the main source of public information disclosure law is Act of the Republic of Indonesia Number 14 of 2008 on Public Information Disclosure (APID). 
including trade secrets law and contract law on one hand, and public law, including public information disclosure law on the other hand. ${ }^{2}$

Trade secrets are part of intangible assets that are increasingly important in international business transactions. Realizing this reality, Indonesia has regulated a specific legislation, Act of the Republic of Indonesia Number 30 of 2000 on Trade Secrets (hereinafter called ATS). Prior to this, trade secret law was regulated by article 1365 of the Indonesian Civil Code (ICC), as a part of general tort law. ${ }^{3}$ This was inadequate in accommodating new needs caused by the developments in the field. ${ }^{4}$

Today, trade secrets law is a part of the Indonesian intellectual property law system. The present Indonesian intellectual property law system includes copyright, patent, trademark, geographical indication, industrial design, the design of the integrated circuit, and protection of plant variety.

Aside from that, through the ATS, the protection of trade secrets is also available through the contract law system. This is particularly important in international business transactions, as a popular cross border legal instrument for the protection of trade secrets. Within the contract law system, the protection of trade secrets is often put in a confidentiality clause of the operative part of the contracts or also

2 Sharon K. Sandeen and Ulla-Maija Melly, "Trade Secrets and the Right to Information: A Comparative Analysis of E.U. and the U.S. Approach to Freedom of Expression and Whistleblowing," North Carolina Journal of Law and Technology 21, no.3 (2020): 61.

3 Every unlawful action, that brings damage to other people, obliges the person by whose fault causing such loss, to compensate such loss, Article 1365 of ICC, Indonesia Civil Code 285 2008) :30-41.

4 The preamble of ATS provides reasons for the enactment of the new law, that is, "to advance industry which is competitive both in the national and international trade, necessary to create a conducive climate for the creations and innovations of the people by providing legal protection for trade secrets as part of the intellectual property rights system;...Indonesia has ratified the Agreement Establishing the World Trade Organization, including the Agreement on Trade-Related Aspect of Intellectual Property Rights/TRIPS with the enactment of Law no. 7 of 1994, and necessary to regulate provisions regarding trade secret." 
called the substantive clauses, comprising the "essential subject matter and transaction" clause. ${ }^{5}$

One specific type of international commercial contracts is the investor-state contracts. This type of international commercial contract has specific characters, among others, because of the involvement of the state or sub-state, as a party to the contracts. The parties to the investor-state contracts are the investor(s) and the state or sub-state. M. Soernarajah defines investor-state contracts as follows.

A contract made between the State, and entity of the State, which, for present purposes, may be defined as an organization created by statutes within a State that is given control over economic activity and a foreign national or a legal person of foreign national. ${ }^{6}$

These contracts are also often called international investment contracts or economic development contracts which have public law elements. They are different from that of purely private international contracts which only have private law elements. Besides regulated by the private law system, the contracts are also regulated by the public law system. Therefore, public law and private law are mixed in regulating the contracts.

One kind of public law instrument is as regulated in APID. APID provides principles and norms on public information disclosure, including public contract disclosure. ${ }^{7}$ This principle does not apply to purely commercial international contracts, but only for public contracts, including investor-state contracts. The term public contract in Dutch is called publiek-rechtelijke overeenkomst. ${ }^{8}$ It is also called a

5 Gurdial Singh Nijar, Drafting for Lawyers: Letters, Opinions, Pleadings, Applications, Affidavits, Judgements \& Orders, Bill of Costs: Practical Legal Skills Series (Kuala Lumpur: Advanced Professional Courses \& Akitiara Corporation, 2006), 54 \& 74.

6 Huala Adolf, the Fundamentals of International Contract Law (Bandung: CV Keni Media, 2007), 126.

7 Simon Butt, "Freedom of Information Law and Its Application in Indonesia: A Preliminary Assessment," Asian Journal of Comparative Law, 8, no. 1 (2013): 17-30.

8 Herlien Budiono, General Doctrine on Contract Law and Its Application in the Notarial Field (Bandung: PT Citra Aditya Bakti, 2009), 25. 
government contract, that is, contracts that are colored by public law. ${ }^{9}$ The public contract or government contracts can be classified generally into two types. First, procurement contracts. Second, non-procurement contracts. One sub-type of the non-procurement contracts is investorstate contracts. ${ }^{10}$

APID limits the applicability of the confidentiality clause that aims at protecting trade secrets in investor-state contracts. As a result, the protection of trade secrets which is done through a broadly defined confidentiality clause is becoming ineffective. The broadly defined confidentiality clause may encompass the whole contract as confidential, therefore, it is inaccessible for public access. To be effective the drafter of the investor-state contracts needs to create a specific model of confidentiality clause unique for the contracts. The new clause should be different from that often used in purely international commercial contracts. This specific model of confidentiality clause should be consistent to both APID ${ }^{11}$ and ATS.

This article employs the doctrinal legal research method. Therefore, it relies on legal authorities. These include primary legal authorities in the form of statutes, contracts, and court decisions. The contracts were selected investor-state contracts of Aceh Province, Indonesia. Besides, it also includes secondary legal authorities in the form of journal articles and books. It also uses tertiary legal authorities in the form of dictionaries. The analysis was performed through legal reasoning.

The following sections of this article will first provide the Indonesian legal framework on trade secrets and contracts. Then, it provides an overview of the act on public information disclosure in Indonesia. Later, it describes the use of confidentiality clauses in selected investment-state contracts. Then, it presents a judicial interpretation of the applicability of the broadly defined confidentiality

9 Mariam Darus Badrulzaman, Various Business Law (Bandung: Alumni, 1994), 66.

10 Yohannes Sogar Simamora, Contract Law: Contract Law Principles on Government Goods and Services Procurement (Yogyakarta: LaksBang PRESSindo, 2009), 60-61.

11 Jodie Partridge, "The Freedom of Information in Indonesia and Australia," Brawijaya Law Journal,13, no. 2 (2015): 41-56. 
clause for the protection of trade secrets in investor-state contracts after APID. Finally, the article explains the need for a balanced model of confidentiality clause for investor-state contracts in Indonesia.

\section{THE INDONESIAN LEGAL FRAMEWORK ON TRADE SECRETS AND CONTRACTS}

The existing law of trade secrets in Indonesia is found in the ATS. The ATS defines trade secrets as, "information in the field of technology and/or business that is not known by the public and has economic values as it is useful in business activities, and the confidentiality of which is maintained by its owner".

The definition is broad because it does not provide the specific meaning of the trade secrets themselves. Therefore, in practice, it may be interpreted broadly to include many things as trade secrets. It is therefore open to multiple interpretations. It seems the drafters of the ATS left it for the judicial institutions to interpret the meaning of trade secrets in implementation. ${ }^{12}$

The reasoning behind enacting the ATC includes the need for advancement of the competitive industry nationally and internationally, the need for supporting the environment of creativity and innovation, and to further implement an international legal regime of General Agreement on Tariffs and Trade/ World Trade Organization (GATT/WTO), where the intellectual property in general and trade secrets in specific are regulated in the Trade-Related IntellectualProperty Rights (TRIPs). ${ }^{13}$

The definition of trade secrets in the ATS does not include other kinds of secrecy which as the influence of the common law system, that is personal data or privacy and government secrets becoming part of the scope of confidentiality clause formulation in investor-state contracts. As a comparison, in the common law system, all kinds of secrecy may include under the law of confidence. ${ }^{14}$ This often reformulates in international business contracts as the confidentiality

12 Sudjana and Elisatris Gultom, Trade Secrets from the Perspective of Consumer Protection (Bandung: Keni Media, 2016), 12.

13 Ibid, 8.

14 Jill McKeough and Andrew Stewart, Intellectual Property in Australia, $2^{\text {nd }} \mathrm{Ed}$, (Sydney: Butterworths, 1997), 59-60. 
clause. Therefore, in the broader meaning, the confidentiality clause in investor-state contracts may include trade secrets, personal data or privacy, and government secrets. These three types of secrecy are often part of the confidentiality clause.

From the perspective of the ATS, both personal data and government secrets cannot be part of the definition of trade secrets. This is because these kinds of secrecy do not have economic value as an element of trade secrets definitions. Even though other elements of the definition can be fulfilled, that is the availability of the secret nature and efforts to maintain the secrecy. In Indonesia as in several other civil law countries, different from many countries with the common law system, personal data and government secrets are regulated under separate laws outside intellectual property law.

As an intellectual property, trade secrets are the property of their owners. Under Indonesian law, this owner can be an individual, a group of individuals (such as a member of a family, a team of researchers, the owner of a non-legal entity company: general partnership or special partnership), and a legal entity. This legal entity or corporate bodies, such as a limited liability company, a cooperative, a state or sub-stateowned companies, and a foundation.

The owner of the trade secrets as the holder of the exclusive rights has the right to prevent others use or exploit commercially the trade secrets. Besides the owner has also the right to prevent others from opening to the public that may damage the economic value of the trade secrets commercially. This means to prevent loss to the owners of the trade secrets.

Therefore, trade secrets law provides the right to the owners to take the case to the court. The intention is to get compensation for the damages. Besides, it is also meant to prevent any forms of trade secret infringements, as regulated in Article 11 ATS.

Different from patent and other intellectual property rights, except for trademark, the term of trade secrets protection is the longest. As far as secrecy can be maintained, meaning that information is not open to the public, it is durable forever. When trade secrets are known by the public, by not infringed the trade secret law, from that time the trade secrets no longer exist. 
Trade secrets, therefore, is an alternative means for protecting technology besides patent. The advantage of protecting trade secrets over a patent is the possibility to protect it for a longer time. Through patent law, technology only obtain 20 years of protection. After that duration, technology becomes the public domain. On the other side, the weakness of protecting technology through trade secrets is the possibility of a leak during the protection. For example, the leak of trade secrets from research and development or reverse engineering activities. In patent no such risk, because the law already protects the use of the technology under the patent system. ${ }^{15}$

An owner of the technology, therefore, has the option to choose either trade secrets or patent, by calculating the risks. If, for example, technology is complicated which is not easy to be known by others or the public or it needs large or expensive investment to find that technology, it is wiser to protect then through trade secrets. Similarly, if the technology is used within a shorter time and easy to be outmoded, the protection through trade secrets is wiser. Generally, experts in the field have opined that the protection of technology through patents and trade secrets are complementary to each other. The choice of one of those is depending much on the particular types of technology and the context surrounding it. Therefore, it should be considered based on case-to-case basis. ${ }^{16}$

Nunoi and Sengon, list the differences between patent and trade secrets, as follows:

1. A patent is protected as a right. Whereas trade secrets do not need such rights. The most important thing in protecting trade secrets is through maintaining its secrecy.

2. In the patent, the scope of technology protected is limited by the scope of the claim is a patent specification. Whereas trade secrets do not have such a defined scope of technology.

15 Luigi Alberto Franzoni, "Trade Secret Law," Quaderni - Working Paper DSE $N^{\circ} 1150$ (June 2020): 1-10.

16 Chagai Vinizky, "Trade Secret Registry" Pace Law Review 35, (2014) : 456 and 534. 
3. The patent has a limited duration of protection. Whereas trade secrets are unlimited.

4. The patent is effective in the country where the patent is granted. Whereas trade secrets do not have a limited territorial area. ${ }^{17}$

The ATS also regulates the transfer of trade secrets through assignments and licenses. This is provided by articles 5, 6, and 6 the ATS. The most popular form of transfer often for a commercial purpose is through a license.

A license is granted by the owner of trade secrets as a licensor to another party as a licensee for a certain duration and with certain requirements to use the trade secrets. Kenneth L. Pott et al explains that a license is a contract made by the owner of intellectual property to avoid possible legal action to the licensee because of infringement if the license is not existing. ${ }^{18}$

In international business transactions, the license is a method as a business instrument that can increase marketing, sales, strategy, finance, which managers have used in innovative ways to achieve the purpose of the company more extensively. ${ }^{19}$ Many international or multinational corporations extend their operation in many other parts of the world, including Indonesia through intellectual property licenses, including trade secrets licenses.

The licensee, on the other hand, can also obtain a meaningful benefit because it does need to provide additional investment for conducting similar research and development. For the licensee, the license is a more efficient method rather than developing alone the technology. ${ }^{20}$

17 Yohtaro Nunoi and Rychiro Sengen, "The Know-How Contract in Japan" in, the Know-How Contract in Germany, Japan, and the United States ed. Herbert-Stump (Deventer: Kluwer Law and Taxation Publishers, 1984), 162-163.

18 Kenneth L. Pott, Licensing Intellectual Property in the Digital Age (Durham, North Caroline: Caroline Academic Press, 1999), 3.

19 Ibid, 10.

20 Jackson H. Knight et al, Patent Strategy for Researchers and Research Manager (New York: John Wiley \& Son, 1981), 51. 
The license agreement is important when there is an import policy in certain countries, for example, prohibiting the import of a certain product, but still an open policy for the license, as an effort to open job opportunities in the country. Other consideration includes a lower level of labor wage in certain countries, which open profitable business opportunity through a license. ${ }^{21}$

Article 7 ATS regulates the applicability of a non-exclusive license. However, according to Article 7 ATS applicable, as far as parties to the license agreement do not regulate differently in the license agreement. This means parties to the license agreement can waive the basic rules on the applicability of non-exclusive license by regulating differently in the license agreements, that is, the parties choose the exclusive license. When the parties freely chose the exclusive license in the contract clause, the basic rule on the applicability of a non-exclusive license becomes inapplicable.

Therefore, the parties based on the principles of freedom of contract can choose either an exclusive license or non-exclusive license. However, when the parties are silent regarding this matter, the non-exclusive license automatically applicable.

The non-exclusive license provides power to the licensor that even though the license has been given to a certain licensor, he or she can still give the license to other licensees or third parties, besides the licensee. For large companies as the holder of trade secrets, this kind of rule is practical enough because it opens more business opportunities through providing the license to many licensees.

Article 8 of the ATS regulates that the license agreement should be registered at the Directorate of Intellectual Property Rights, Department of Law and Human Rights of the Republic of Indonesia, by paying the fee. If it is not registered, it will not give a legal effect on the third parties. This means, the unregistered license contracts only applicable to licensor and licensee alone. After registration, the license contract documents than being announced in the trade secret gazettes.

21 Yohtaro Nunoi and Rychiro Sengen, "The Know-How Contract in Japan" in, the Know-How Contract in Germany, Japan, and the United States ed. Herbert-Stump (Deventer: Kluwer Law and Taxation Publishers, 1984), 9-10. 
Article 9 of the ATS also regulates the limitation of a license contract. Here, the act limits the applicability of the principle of freedom of contracts. Based on the principles of the freedom of contracts parties are free to choose any form of contract and to regulate anything whatever they want to be put in the contract clauses. The reasoning behind limiting the applicability of the freedom of contract here is for protecting the public interest.

Article 9 also provides rights for the government to prohibit license agreement with a clause that may affect negatively the Indonesian economy and unfair business practices. If the government, here the Directorate General of Intellectual Property, Department of Law and Human Rights of the Republic of Indonesia considers that the content of the contracts employs one of the above requirements, it has the right to reject the recording of the license agreement.

Article 9 ATS provides, as follows:

(1) A licensing agreement shall not contain any provisions that may directly or indirectly damage the Indonesian economy or any provisions that can create an unfair competition as regulated in the prevailing laws and regulations.

(2) The Directorate General shall refuse any request for the recording of a licensing agreement that contains the provisions as referred to in paragraph (1).

(3) Provisions regarding the requirements and procedure of licensing agreement shall be further regulated by Presidential Decree.

In Article 9 of the ATS, the legislator of the Act tries to balance the protection of both the private interests of licensor and licensee, and the public interest of state or community at large. On the other hand, they protect the private interest as part of the private law regime of property. But this protection is given as far as consistent to the interest of state or public at large as regulate part of public law regime. This provision is aimed at preventing the negative effects or the undesirable result of trade secret licensing practice in business transactions. 
When the private law regime conflicts public law regime, the public law regime dominates. In other words, the border of private law protection is when public law regulates them differently. Where there is no public law regime, private law is applicable based on the principle of party autonomy or the principle of freedom of contract.

In general, according to Herbert Stump, an international license agreement often provides the following clauses. It includes the scope of the license, the nature of the license (exclusive or non-exclusive), sublicense, license jurisdiction, technical assistance, licensor's labor, and worker assistance, training for licensee's labor and worker, liability for third parties claim, technical implementation, commercial exploitation, product quality, the effect of non-fulfilment of product quality, modification and repairmen of the lower standard quality of the product, modification and development of the product by the licensee, payment for the transfer of information, and payment of royalty. Aside them, additional clauses are as follows a time when the right to royalty increase, tax, product mark, financial examination and report, the obligation to use the product from the licensee, market loss, the obligation to buy the product of licensor, confidentiality, antipiracy, the term of the license, termination of the license contract, transitional clause, governing law, and arbitration jurisdiction. ${ }^{22}$

The license of trade secrets abroad faces the risk of a leak. To prevent the leak, both in international license contracts and investorstate contracts, the parties often provide a specific clause on protecting trade secrets. The clause is often named with a confidentiality or confidentiality clause. The clause may be drafted broadly and narrowly based on the principle of freedom of contracts. However, for a specific type of contract, like investor-state contracts, the formulation should be consistent with the rules in APID. Other forms of effort to protect the trade secrets are through employment agreement providing clauses on employee's obligation to protect the company trade secrets,

22 Huala Adolf, the Fundamentals of International Contract Law (Bandung: CV Keni Media, 2007), 457. 
equipped with the internal procedure of handling problems. ${ }^{23}$ Another method, of course, is through socialization programs. ${ }^{24}$

The protection of trade secrets is also available under the law of contract. The main source of existing Indonesian contract law is found in the ICC. The ICC regulates contracts in Book Three, part of the law of obligations. The law of obligations consists of two main classifications. First, obligations based on the contract. Second, obligations are based on statutes. The latter includes the law of torts.

Among the most important features of Indonesian contract law is the stipulation of several important principles. These include freedom of contract, pacta sunt servanda, and good faith.

Article 1338 ICC provides, as follows: ${ }^{25}$

All agreements that are made legally shall apply as the law between the parties thereto. An agreement is not revocable except with the consent of both parties, or for the reasons by the law are sufficient therefor. An agreement must be performed in good faith.

Article 1338 paragraph (1) of the ICC above regulates the applicability of two important contract law principles, that is, the principle of freedom of contract and the principle of pacta sunt servanda. Article 1338 paragraph (2) of the ICC above strengthens the applicability of the principle of pacta sunt servanda. Whereas, Article 1338 paragraph (3) of the ICC above regulates the applicability of the principle of good faith.

These general contract law principles are also applicable to international commercial contracts, including investor-state contracts.

23 Kholis Roisah and Putri Purbasari Ratnaningtyas, "Protection of Trade Secret Ownership in Company: Survey in Phapros and Lombok Gandaria Foods Industry," Journal of Legal, Ethical and Regulatory 22 (2019): 4563.

24 Idul Hanzal Alid and Lailasari Ekaningsih, "How Government Provides Legal Protection for Trade Secrets,". Journal of Law and Legal Reform 1 (2020): 222.

25 The Republic of Indonesia, In Indonesian Civil Code (Kitab UndangUndang Hukum Perdata), Trans Rany Mangunsong, BRM Office (Jakarta: PT Gramedia Pustaka Utama, 2008), 281. 
The applicability of this domestic contract law is based on the choice of law doctrine or the principles of international private law.

In addition, the investor-state contracts in Indonesia should also follow the public law principles and rules which provide additional requirements for the validity of the public contract is a type of formal contracts based on the Act of the Republic of Indonesia Number 25 of 2007 on Investment (hereinafter called as AI). This is based, among others, on Article 3 figure (a) of thw AI provides that the investment is based on the principle of legal certainty. Besides, Article 15 of the AI provides that each investor should follow all relevant statutory provisions related to investments.

For Aceh Province, AI is a general rule (lex generalis), because it has a specific rule (lex specialis), that is, Act Number 11 of 2006 on Governing of Aceh (hereinafter called as AGOA). AGOA provides special autonomy for Aceh Province on investment. To implement AGOA, several implementing regulations have been provided both by central and local governments, among others, on investment and oil and gas management in the province.

Based on the principles of both Indonesian domestic contract law and international commercial contract law, the limitation of contract implementation is the availability of contrary public law regimes. When the public law provision existed, the contract provision becomes inferior. One of the relevant public law regimes is the APID. The APID, among others, aims to promote public contract transparency.

Similar to many other international commercial contracts, the drafting of investor-state contracts involved 3 (three) main phases. These as stated by Van Dunne include pre-contract, contract, and postcontract. ${ }^{26}$ In the pre-contract phase, several sub-phases may be involved, including preliminary negotiation, memorandum of understanding, legal and financial due diligence, and final negotiation. In contracts, the phase may also include several sub-phases, such as preparation of the first draft of the contract, contract review, contract revision, final draft, and signatory. Whereas in the post-contract phase,

26 Mariam Darus Badrulzaman, Various Business Laws (Bandung: Penerbit Alumni, 1994), 36. 
it may include several other sub-phases, including implementation, interpretation, and dispute settlement (when needed).

Generally, the structure of an international investment contract may include the following several elements. First, title. Second, introductory paragraph. Third, parties. Fourth, recitals. Fifth, operative part. Sixth, closing paragraph, Seventh, signatory part. Eight, appendices (if any). ${ }^{27}$

The operative part is where all rights and obligations of the parties are put. The rights and obligations may fall under one of the two classifications. First, commercial transaction clauses. Second, legal clauses. The commercial transaction clauses involved both the commercial interest of the domestic investors (state and/or sub-states institutions) and foreign or international investors. The legal clauses which are often called boilerplate clauses involved general legal provisions. These clauses are intended to anticipate possible legal risks faced by the parties in the implementation of the contracts. ${ }^{28}$

As far as consistency to the contract law rules and principles, and nor contradictory to rules and principles of public law regime, the boilerplate clauses in the operative part made by the parties are binding and enforceable. Under Indonesian law, as Gunawan Muhammad notes that, "without prior fairness test, a boilerplate contract shall be legally and/or commercially acceptable". ${ }^{29}$

The boilerplate clauses in an international investment contract often comprise of several more specific clauses. These include the choice of law, choice of forum, dispute settlement, non-performance, force majeure, amendment, termination, and confidentiality. The confidentiality clause, include mainly trade secrets protection. ${ }^{30}$

27 Sanusi Bintang, Drafting International Contracts (Banda Aceh: Gamna Publishing, 2017), 71.

28 Ibid, 92.

29 Gunawan Muhammad, "Boilerplate Contract; A Perspective from Indonesian Laws and Regulations," Palarchs Journal of Archeology of Egypt/Egyptology 4, (2020): 207.

30 Ibid, 74-75. 


\section{An overview of Act on Public Information Disclosure}

The Act on Public Information Disclosure (APID) in Indonesia was promulgated on April 30, 2008. Based on Article 14 of the APID, the act should be in force, at least April 2010, two years from the promulgation. Among the important legal concepts used in the APID includes information, public information, and public body. In other counties, this act is also named as the Act on Information Freedom.

Based on Article 3, the act was promulgated generally for guaranteeing citizen rights to know public information, to motivate public participation in the public policymaking process, to increase role in the management of the public body, achieving good governance, to understand reasons behind the essential public policy, to develop science, and to increase the quality of public information management and service.

The act defines information in a broader meaning, to include any form or media. Regarding contracts, this means any form of contract and medium. This includes international investment contracts. Article 1 para 1 of the APID provides that information is:

...explanation, statement, idea, and marks that have values, meaning, massages, either data, fact or elucidation that can be seen, heard, and read, that served in various forms consistent with the development of electronic and non-electronic information and communication technology.

The APID defines public information also in a broader meaning to include all information in a public body. Therefore, as far as the content of the contracts contains public interest, that information in the public body is classified as public information. This also similar regarding contracts, as far as the contract contains public interest, or as the public contract, the contract is classified as public information. Article 1 para 2 APID provides that public information is:

Information produced, saved, managed, sent and/or received by a public body, regarding the management, state management and/or manager and management of other public bodies that are related to the public interest.

The APID also defines public body broadly, broader than mere state management (including local government management, but also other types of the public body that in the management of the public 
body at least part of its budget comes from the state budget or local budget., public gift or international assistance. This implies that regarding public contracts, like international investment contracts, the contract is not only involved state public body, but also other public bodies, include state-owned enterprises, local government-owned enterprises, and also foundations, as far as connected to the public budget. Article 1 para 3 the APID provides that the public body is:

Executive, legislative, and judicial institutions and other bodies that have main function and duties related to state management, that part or all funding is from the state budget and/or local government budget or nongovernment organization as far as part or whole funding is from the state budget and local government budget, public contribution and/or overseas assistance.

All provisions in the APID above can also be applied to public contracts, such as international investment contracts. This means public contracts are open to the public, the exception to these rules is tight and limited. The contract should be available to the public expedited, timely, inexpensively. When a contract is considered as exempted information, that is, secret information based on act, fairness and public interest should be based on a consequential test provided by a related officer of information and communication.

In general, the principle provided by the APID is qualitatively consistent with the international standard on public information disclosure. This includes completeness, primacy, timeliness, ease of physical and electronic access, machine readability, nondiscrimination, use of commonly owned standards, licensing, permanence, and usage cost. ${ }^{31}$ Even though the APID only explicitly mentioned 4 principles, but the formulation is quite condensed. Several of the principles even though not mentioned in Article 2 the APID, can be found or inferred in other articles of the APID. The 4 principles of the APID include, as follows. First, the openness of each public information. Second, the tight and limited of exempted information. Third, timeliness, inexpensive, and simple procedure. Fourth, the

31 Wendy Ginsberg, Government Transparency and Secrecy: An examination of Meaning and Its Use in the Executive Branch: CRS Report for Congress (Washington, D.C.: Congressional Research Service, 2012), 3-4. 
secrecy of exempted information is based on law, fairness, and public interest based on a consequential test.

Article 11 of the APID provides the type of public information which should be available at any time by the public body. This information includes, among others, "contract between the public body and the third party," as regulated in Article 11 para 1 figure (e) of the APID. Therefore, in principle, each public contract or government contract, including an international investment contract is considered as public information that should be available at any time by the public body. There is no further explanation in Article 11 of the APID regarding the meaning of the word "contracts." There is also no further explanation of whether the contract openness includes all phases of the contract drafting process, pre-contract, contract, and post contract.

Article 17 the APID provides specifically exempted information. This means that even though public information is open, as regulated in Article 11 the APID, but can be closed if it fulfills the criteria of exempted information. Article 17 the APID provides 10 exempted information.

First, the potential of the hindrance of the legal enforcement process. Second, the potential to infringe intellectual property protection and to cause unfair business practices. Third, the potential for the risk of security and defence. Fourth, the potential to show Indonesian natural resources. Fifth, potential to risk national economic stability. Sixth, potential to damage foreign relation interest. Seventh, the potential to open the content of private authentic deeds and similar documents. Eighth, potential to divulge privacy. Ninth, the potential to open the internal memorandum of the public body. Tenth, the potential to divulge the information that is prevented by statutes.

Among the 10 types of exempted information above, are those related to contracts, including investor-state contracts. This information includes, as follows. First, the one that if it is open potential to infringe intellectual property protection and to cause unfair business practices, Second, the one that if it is open is potential to risk national economic stability (here are initial steps of foreign investment).

If the above rules of the APID are applied in an investor-state contract, it will show the characteristics of the investor-state contract is the existence of transparency. First, as a general rule, an investor-state 
contract is a public contract, which should be open at any time. Second, as an exception, the investor-state contract can be classified as exempted information, which is tight and limited based on law, fairness, and public interest, because if it is open will be potential to infringe intellectual property protection, particularly trade secrets, and to cause unfair business practices, and/or potential to risk national economic stability, particularly initial steps of foreign investment.

The APID provides a general rule that an investor-state contract should be open at any time. This can be read in Article 2 of the APID by formulating that, "information... by public body...that are related to the public interest." Therefore, any public body within the meaning of APID, should apply this principle of contract transparency based on Article 2 of the APID. However, this rule is not absolute, but relative. This is because, besides the above general rules, the APID also provides the limitation or the border of the application of the rules. These rules are called exemption rules that open the opportunity for the public information, that is, investor-state contracts to be closed for public access, as far as the requirement fulfilled.

The exemption rules can be found in Article 17 of the APID regulating exempted information. Because in general under the APID all public information, including investor-state contracts are open to the public as regulated in Article 2 of the APID, the rules in Article 17 of the APID are as an exceptional rule, applicable limitedly under certain circumstances. From the 10 types of exempted information provided by Article 17 of the APID, those relevant to investor-state contracts includes the second category of the exemption called, "the information that is potential to infringe intellectual property protection, and to cause unfair business practices. Besides, it is also the fifth exemption under Article 17 of the APID, that is, "the information that is potential to risk national economic stability".

The most important exemption in relation to the topic of this article is as provided in the second exemption above, that is, the one that is potential to infringe intellectual property and to cause unfair business practices." Here, the APID uses a broader term that has a broader meaning, that is, intellectual property. One and the most relevant intellectual property to this topic is regarding trade secrets, as mainly regulated in the ATS. 


\section{THE USE OF A CONFIDENTIALITY CLAUSE IN INVESTOR- STATE CONTRACTS}

Selected international investment contracts obtained from the Province of Aceh, Indonesia, shows that the formulation of confidentiality clauses by investor-state contract drafters differed. These include broad formulation and narrow formulation.

The broad formulation may fully be workable in a purely international commercial contract, but may not be binding in investorstate contracts because they are contrary to the principle of public information disclosure under APID. Whereas the narrow formulation of the confidentiality clause is maybe not enough to guarantee the protection of parties' trade secrets. Therefore, a balanced confidentiality clause is needed for investor-state contracts in Indonesia.

A sample of the existing confidentiality clause provides:

For this agreement, Confidentiality Information means this agreement and all information related to the Project or this Agreement which is furnished by one Party (the Disclosing Party) to the other Party (Receiving Party), whether furnish before or after the date of this Agreement, whether tangible or intangible and in whatever form or medium provided, whether marked CONFIDENTIAL, or not marked CONFIDENTIAL, as well as information generated by the Receiving Party or by its representatives that contains, reflects, or is derived from the furnished information.

Another sample of confidentiality clause provides:

...Confidential Information means the terms and conditions of these Agreements and all information provided by one party to the other Party under this Agreement and/or for the purposes of...Project and its project Activities, including (without limitation) information concerning the business and affairs of a Party and its affiliates and customers, and any business analysis, information, pricing, and other information.

Both sample clauses above use broadly defined confidentiality clauses. ${ }^{32}$ They cover the broad meaning of confidentiality as the object

32 Gurdial Singh Nijar, Drafting for Lawyers: Letters, Opinions, Pleadings, Applications, Affidavits, Judgements. 
of its protection. This can be seen from the phrase ".., this agreement and all information related to this Project or this agreement..." It can also be seen from the Phares: "the terms and conditions of this Agreement and all information provided...and other information." Therefore, it also encompasses the broad meaning of trade secrets as part of the confidential information.

Under the contract law system, based on the principle of freedom of contract (party autonomy), the clauses are binding. ${ }^{33}$ This is true for the majority of international commercial contracts. But the problem will arise when this type of clause is used in international investment contracts. This because international investment contracts are unique. They are specific types of international commercial contracts that have specific characteristics. One of the most important characteristics is the applicability of the public law system besides the private law system as a consequence of state involvement as a party to the contracts. In other words, investor-state contracts are not merely international commercial contracts, but also public contracts. ${ }^{34}$

Therefore, when drafting the investor-state contracts, drafters need to be aware of the applicability of the public law provision as regulated in APID. APID mandates a public body to provide public information to those who request it. Article 7 Paragraph (1) provides that "public body shall provide, disclose and/or issue Public Information under its authority to Public Information requester, except for exempted information according to regulations."

Article 11 paragraph (1) sub e of APID provides that information which shall be made available at all times by the public body includes "agreement between Public Body and third parties." Whereas article 17 regulates exempted information, includes:

b. Public Information if disclosed and provided to Public Information Requester could obstruct protection of intellectual property rights and protection from unfair competition;...Public

\& Orders, Bill of Costs: Practical Legal Skills Series (Kuala Lumpur: Advanced Professional Courses \& Akitiara Corporation, 2006), 75.

33 Moch. Isnaeni, "Developing Contract Law Principles as Fundamentals for Business Activities in Indonesia," in The Development of Private Law in Indonesia (Yogyakarta, Laksbang Grafika, 2013), 20.

34 Yohannes Sogar Simamora, Contract Law: Government Procurement Contract Law Principles (Yogyakarta, LaksBang PRESSindo, 2009), 80. 
Information, if disclosed and provided to Public Information Requester, could impose harm to national economic resilience, namely as follows:...5. any initial plan of foreign investment.

The term intellectual property rights here mainly mean of protecting trade secrets. Therefore, trade secrets are part of the exempted information. The problem is that there is no clear definition of trade secrets in the ATS or other related legislation. ${ }^{35}$ Therefore, it is left to the judiciary to interpret the meaning on a case-to-case basis.

\section{A CASE ON THE APPLICABILITY OF BROADLY DEFINED CONFIDENTIALITY CLAUSE}

There was a case in the Central Information Commission of the Republic of Indonesia (hereinafter called CICRI), ${ }^{36}$ LSM Koalisi Untuk Hak Atas Air (KRUHA) v. Perusahaan Daerah Air Minum (PDAM) Provinsi DKI Jakarta. ${ }^{37}$

KRUHA is a non-governmental organization that has the main activity to guarantee the fulfillment of people's rights to clean water, whereas PDAM DKI Jakarta is a regional-owned company that has the main activity to provide clean water services for peoples of DKI Jakarta. The company is owned by the Special Regional Government of Jakarta Capital City.

In 2011, KRUHA requested public information disclosure to PDAM DKI Jakarta, that is, cooperation contracts between PDAM DKI Jakarta and PT Palyja and PT TPJ/Aetra. PT Palyja is a subsidiary of a foreign company established in Singapore, whereas PT TPJ/Aetra is a subsidiary of a foreign company established in French. Therefore, a cooperation contract is a legal instrument for supporting a public-

35 Sudjana and Elisatris Gultom, Trade Secrets from the Perspective of Consumer Protection (Bandung: Keni Media, 2016), 62.

36 CIRCI is a semi-judicial institution which is statutorily enacted and according to Article 23 APID and its Explanatory Note it has the power to produce a decision similar to that of the court.

37 Decision of the Central Information Commission of the Republic of Indonesia (CIRCI) Number 391/XII/KIP-PS-M-A/2011. 
private partnership (PPP). The type of business transaction behind the PPP is quality clean water service for the peoples of DKI Jakarta. ${ }^{38}$

PDAM DKI Jakarta rejected the request for accessing the cooperation contracts for reasons of the existence of a confidentiality clause within the contracts. The clause provides that principally the whole content of the contracts is confidential and if a party needs to disclose it, it has to get permission from the other party. KRUHA argued that water service is part of the public law system, not a private law system which should operate transparently based on Indonesian domestic law. Because of its dissatisfaction, KRUHA then brought the case to CICRI in 2012. ${ }^{39}$

After a mediation process was failed, CICRI then provided the adjudication process based on rules of procedure of the APID. CICRI then decided the first legal issue on whether the cooperation contract was the exempted information. CICRI held that, as far as the information in the contracts is related to private rights, they are regulated fully by private law. However, according to CICRI, here the management of water is principal as res commune which should be under the control of the public law system, not a private law system. Therefore, according to CICRI the rejection of access to contract information by PDAM DKI Jakarta is irrelevant. ${ }^{40}$

Then, CICRI decided the second legal issue on whether financial projection and addendum of the cooperation contract used to ascertain prices for water service are categorized as exempted information. According to CICRI, the financial projection is as a part of the addendum of the cooperation contracts. CICRI held that because PDAM DKI Jakarta and PT Palyja were still in the step of negotiation, the addendum and the financial projection are exempted information which has no obligation to be disclosed to the public. ${ }^{41}$

38 LSM Koalisi Rakyat Untuk Hak Atas Air (KRUHA) v. Perusahaan Daerah Air Minum (PDAM) Provinsi DKI Jakarta, 1.

39 LSM Koalisi Rakyat Untuk Hak Atas Air (KRUHA) v. Perusahaan Daerah Air Minum (PDAM) Provinsi DKI Jakarta, 2-3.

40 LSM Koalisi Rakyat Untuk Hak Atas Air (KRUHA) v. Perusahaan Daerah Air Minum (PDAM) Provinsi DKI Jakarta, 30.

41 LSM Koalisi Rakyat Untuk Hak Atas Air (KRUHA) v. Perusahaan Daerah Air Minum (PDAM) Provinsi DKI Jakarta, 36. 


\section{NEED FOR A BALANCED MODEL OF THE CONFIDENTIALITY CLAUSE FOR THE INVESTOR-STATE CONTRACTS}

The broad confidentiality clause in investor-state contracts needs to be adjusted to make it consistent with public law as regulated in APID. The balanced model of the confidentiality clause is that which in on one hand can accommodate the interest for the protection of trade secrets as intended by legislators of ATC, and on the other hand, can accommodate the interest for public information disclosure as intended by legislators of APID. This reasoning can be based also on one of the principles of Indonesian contract law, that is the principle of equilibrium. Based on the principle of equilibrium, there should be a balance between the rights and obligations of both parties in the contract clauses. $^{42}$

The formulation should be between the two conflicting interests, the trade secrets protection, and the public information disclosure. This is a way to apply the principle of equilibrium under Indonesian contract law. Therefore, the formulation should not be too broad and also should not be too narrow, to achieve balanced protection of both interests. ${ }^{43}$

For that purpose, the placement of the provision on the confidentiality clause for trade secrets protection can be arranged in several relevant articles of the operative part of the international investment contracts. For example, it can be started by formulating an operational definition of the confidential information and then equipped with relevant obligations to the parties.

For example, the definition can be expressed as; confidential information is information as a part of a contract document which is confidential because it is regulated so by prevailing laws, and/or as trade secrets, personal data, state secrecy, technical information of a product or a process, inventive ideas developed from the confidential information, and other types of information related to investments or

\footnotetext{
42 Mariam Darus Badrulzaman, Various Business Law (Bandung: Alumni, 1994), 43.

43 Herlien Budiono, The Principle of Equilibrium for Indonesian Contract Law: Contract Law Based on Wigati Principles of Indonesia (Bandung: PT Citra Adytia Bakti, 2015), 552.
} 
business transactions regulated by the contracts, which are expressed in writing and clear manner as the confidential information, subject to exceptions based on public law measures. ${ }^{44}$ The obligations can be put in boilerplate clauses.

\section{CONCLUSION}

Each type of international commercial contracts may have their own specific characteristics which are not available to other types of contracts within their classifications. These specific types of contracts include investor-state contracts which have mixed elements of both private law and public law. When certain public law provisions are available, they should be followed by parties to the contracts. These include the obligation to disclose public information regulated by the contracts. This limits the applicability of the broadly defined confidentiality clause for trade secrets protection often used in other types of international commercial contracts. The confidentiality clause of investor-state contracts should provide balanced protection of both state interest for public information disclosure and investors' interest in protecting trade secrets. The present practice of using a broadly defined confidentiality clause in many investor-state contracts needs to be altered by using a more rigidly defined confidentiality clause to be consistent with the APID.

The drafter of investor-state contracts needs to provide clear provisions regarding these obligations. The obligations, for example, can be expressed as follows:

Article 1

This contract is a public document that can be accessed and used by whoever needs it as indicated and regulated by APID, except part of the contract referred to as Confidential Information.

Article 2

Each party who has Confidential information should inform and declare in writing and in a clear manner the Confidential information to be maintained and protected by another party.

Article 3

44 Ibid. 
The duration of obligations to maintain and protect the Confidential information starts from the time of consensus reached between Parties to contract.

\section{Article 4}

Any party should not disclose the Confidential information to the third party or any other individuals, except by written consent of the Party who own it and/or as regulated by public law measures.

\section{Article 5}

The exception to the obligations as outlined in Article 4 is given to certain employees and workers who work under certain industrial relation or contractual relation in the Project activities, whom themselves are subjected to confidentiality obligations or other relevant legal measures.

In case of more detailed provisions of confidential information are needed, the obligations can also be put in a separate confidentiality agreement or in a schedule. In this regard, as the main agreement, the investor-state contracts can provide a designation clause on the existence of the separate confidentiality agreement or the schedule. The balanced confidentiality clause of an investor-state contract will facilitate better implementation of the contract and will prevent possible future legal disputes. 